\title{
Parcul Carol I - mozaic al valorilor culturale
}

Parcul Carol I reprezintă un ansamblu urbanistic, arhitectural și peisagistic cu multiple amprente de natură istorică, chiar anterioare constituirii sale, care deține numeroase calități și caracteristici pentru a constitui o imagine complexă a epocilor traversate în decursul timpului.

Ca pledoarie pentru cele afirmate mai sus, voi prezenta în cele ce urmează o serie de observații actualizate, evidențiate în cadrul studiului istoric de fundamentare a intervențiilor, elaborat pentru P.U.Z. Parcul Carol I. În acest sens, consider ca relevante aspectele referitoare la statutul juridic de protecție a imobilului, cele privind evaluarea urbanistică, arhitecturală și istorică, precum și reglementările generale de intervenție propuse cu acel prilej. Astfel, deși datele de cercetare referitoare la evoluția istorică a zonei și a imobilului studiat reprezintă suportul fundamental pentru studiul amintit, am considerat că includerea lor în această lucrare ar constitui doar o reluare a informațiilor deja cunoscute și prezentate în varii publicații.

****

Referitor la statutul juridic de protectie a valorilor culturale, pe care îl dețin parcurile și grădinile în general, trebuie precizate următoarele aspecte semnificative identificate în Lista Monumentelor Istorice actualizată în anul 2015 (L.M.I.-20I5) .

Majoritatea pozițiilor ce conțin specificația „parc” reprezintă grădini ale palatelor sau conacelor boierești și nobiliare, cu o mai mare extindere în Transilvania și cu o pondere redusă a obiectivelor în exteriorul arcului carpatic.
Pentru București în L.M.I.-20 I5, cu excepția grădinilor conacelor sau palatelor, există doar următoarele opt parcuri și grădini clasate ca poziții individualizate:

I. B-II-a-A-I8300 / Parcul loanid - sf. sec. XIX - încep. sec. $X X$

2. B-II-a-A- I830I / Grădina Icoanei - sf. sec. XIX - încep. sec. $X X$

3. B-II-a-B- 18444 / Parcul Plumbuita - sf. sec. XIX

4. B-II-a-B-I8508 / Grădina Botanică - sf. sec. XIX încep. sec. $X X$

5. B-II-a-A- 18802 / Parcul Herăstrău - prima jum. sec. XX

6. B-II-a-B-I8982 / Parcul Kiseleff - sf. sec. XIX

7. B-II-a-A-190I6 / Parcul Carol [-I-] - sf. sec. XIX prima jum. sec. $X X$

8. B-II-a-A- 19655 / Grădina Cișmigiu - sec. XIX

la care se mai pot adăuga și următoarele două poziții:

9.B-II-a-A-19202 / Grădina Cinema Capitol - înc. sec. XX 10. B-II-a-A-2 1045.06/Parcul dendrologic Ansamblul Institutului de Cercetări Agronomice al României, azi Academia de științe Agricole și Silvice „Gheorghe lonescuSisești” - prima jum. sec. XX.

Parcurilor și grădinilor trebuie să li se acorde o atenție deosebită în ceea ce privește autorizarea oricăror intervenții, cu atât mai mult cu cât numărul foarte redus al acestora reprezintă doar $0,05 \%$ din totalul monumentelor istorice clasate în Lista Monumentelor Istorice la nivel național și $0,38 \%$ din cele 265 I de poziții pentru Municipiul București, în raport cu situația din alte țări, cum ar fi Franța, care deține în lista monumentelor istorice un procent de $6 \%$ parcuri. 
În ceea ce privește Parcul Carol I, în conformitate cu L.M.I.-20I5 pentru Municipiul București, imobilul situat în Piața Libertății, sectorul 4, delimitat de: Piața Libertății, Str. G-ral. Candiano Popescu, Calea Șerban Vodă, Str. Cuțitul de Argint și Str. Dr. Constantin Istrati este menționat la poziția $1300 \mathrm{cu}$ codul B-II-a-A-19016, clasat în grupa $A$, ca ansamblu reprezentativ pentru patrimoniul cultural pe plan național. (Fig. I)

Totodată, conform aceleiași liste, imobilul Parcul Carol I este situat în zonele de protecție ale mai multor imobile clasate ca monumente istorice în grupele A și $B$.

În conformitate cu P.U.G. pentru Municipiul București, elaborat în 1999, Parcul Carol I deține statutul de zonă plantată de importanță municipală, precum și de Zonă Construită Protejată nr. 82 - parcuri istorice.

Rezultă faptul că regimul de protecție al Parcului Carol I este unul complex, care se referă atât la patrimoniul cultural, cât și la cel natural. Teritoriul asupra căruia se exercită categoriile de protecție mai sus amintite conține atât întreaga suprafață a Parcului Carol I, cât și pe cea a parcelelor învecinate (Muzeul Tehnicii - prof. ing. Dimitrie Leonida, Castelul Țepeș Vodă, Biserica Schimbarea la Față - Cuțitul de Argint și Institutul Astronomic [Constantin] Bosianu).

****

Analiza referitoare la valoarea culturală pe care o deține Parcul Carol I evidențiază caracteristicile și calitățile urbanistice, arhitecturale, artistice, peisagistice și istorice, ținând cont de următoarele criterii de analiză:

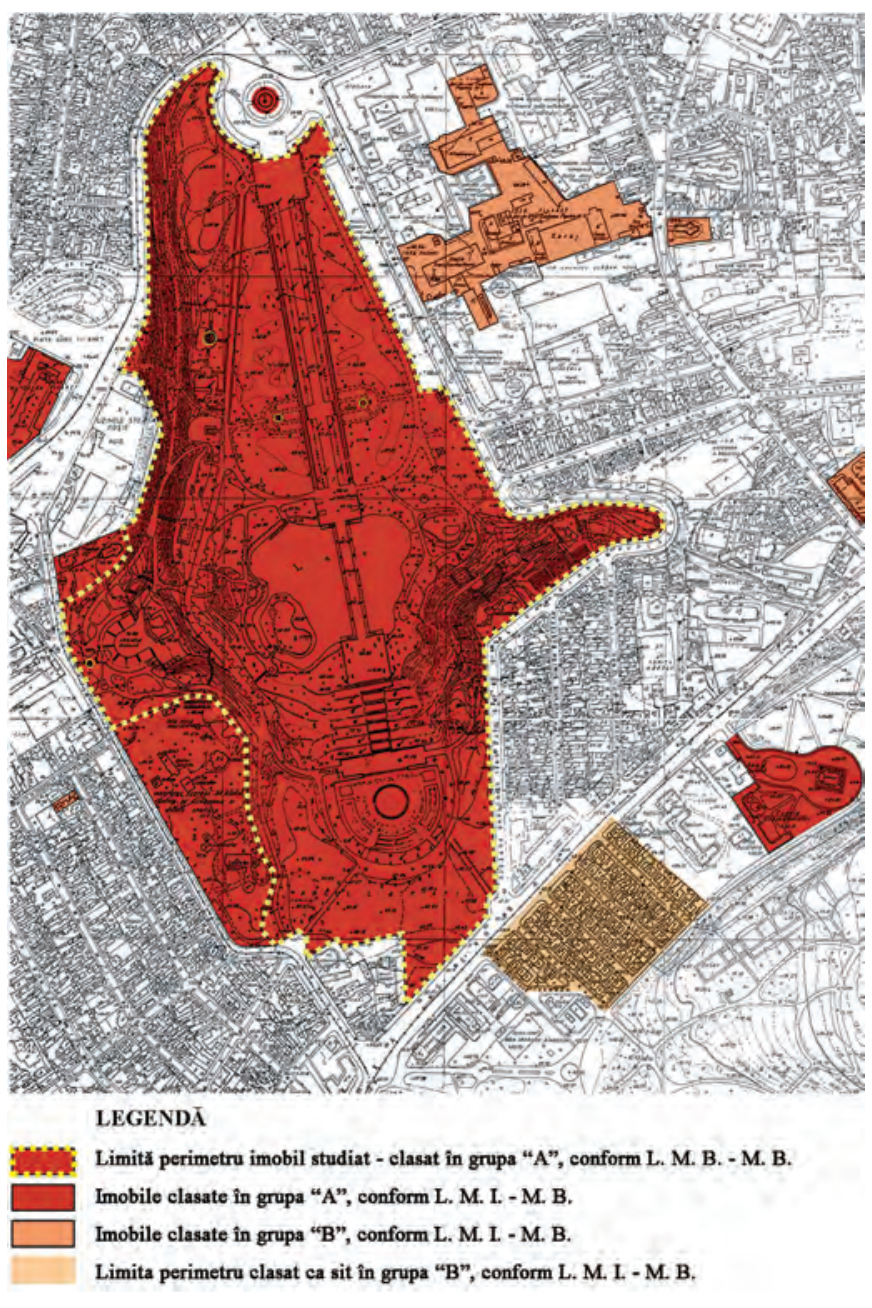

Fig. I - statutul juridic de protecție a valorilor culturale LMI-MB 2015 
- criteriul vechimii;

- criteriul referitor la valoarea arhitecturală, artistică și urbanistică;

- criteriul referitor la frecvență (raritate și unicitate);

- criteriul referitor la valoarea memorial-simbolică.

\section{Criteriul vechimii}

Edificarea parcului aparține în mod predominant perioadei 1906-1935, iar completările din anii 1959-1963 continuă, de fapt, axul monumental, a cărui intenție compozițională fusese preconizată încă din 1919 .

Majoritatea componentelor parcului datează din aceeași perioadă, cu excepția celor două fântâni decorative, care aparțin unei etape anterioare constituirii parcului, respectiv din 1870 .

Ponderea intervențiilor de după al doilea război mondial este semnificativă, dar în concordanță cu concepția anterioară. Monumentul Eroilor, realizat pe amplasamentul fostului Muzeu Militar National (incendiat în urma bombardamentelor si demolat după cutremurul din 1940) reprezenta o inițiativă a Regelui Ferdinand, care încă din 1919, preconiza realizarea unui Pantheon al Eroilor Neamului.

În consecință, vechimea Parcului Carol I se consideră ca aparținând perioadei 1906-1935, cu elemente arhitecturale și de artă plastică din a doua jumătate a secolului al XIX-lea, dar și din a doua jumătate a secolului al XX-lea.

Conform metodologiei în vigoare, imobilele edificate între anii I 870 și 1920 primesc calificativul mediu. Acest criteriu se referă la toate categoriile de imobile, fără a ține cont de noutatea unui anumit tip de program arhitectural și/sau urbanistic.

Parcul Carol I se înscrie, însă, în categoria primelor parcuri publice realizate în România, ceea ce îi conferă o valoare foarte mare și chiar excepțională la celelalte categorii de criterii.

\section{Criteriul referitor la valoarea arhitecturală, artistică și urbanistică}

Acest criteriu are ca scop stabilirea valorii imobilului din punct de vedere estetic, funcțional și tehnic.

Ca rezultat al evoluției sale în timp, Parcul Carol I este la ora actuală un ansamblu coerent cu un caracter urbanistic, arhitectural și peisagistic de valoare excepțională, generat de următoarele caracteristici semnificative: unitatea compozițională a ansamblului, valoarea componentelor artistice, notorietatea autorilor și dimensiunea funcționalsimbolică.

\section{Unitatea compozițională a ansamblului}

Ansamblul parcului este perfect înscris în teren, urmărind atât topografia reliefului, cât și vechiul drum dintre câmpie și cornișă. Trebuie semnalată articularea armonioasă, făcută cu multă abilitate între cele două structuri compoziționale întîlnite frecvent în parcurile, grădinile și, în general, în amenajările peisagistice europene din jurul anului 1900. Astfel, se remarcă o porțiune de factură regulată, liniară, a zonei centrale situată pe platforma inferioară (Fig. 2), care este continuată și pe platforma superioară, precum și o porțiune de factură liberă, cu caracter romantic, care se integrează organic atât în prima structură, cât și în vecinătățile imediate (Fig. 3).

Tratarea peisagistică a traseelor aleilor împreună cu gruparea liberă a acestora au rolul de a prelua neregularitățile terenului și denivelările accentuate ale pantei dintre cele două platforme, asigurând în acest mod spațiile corespunzătoare diferitelor funcțiuni de agrement.

Acestă compoziție articulată subordonează plantația care, prin dispunerea marilor mase, prin accente, prin alăturarea esențelor variate și prin ierarhizarea lor - de la masive plantate cu arbori (printre care există încă numeroase exemplare seculare sau esență rară) până la 

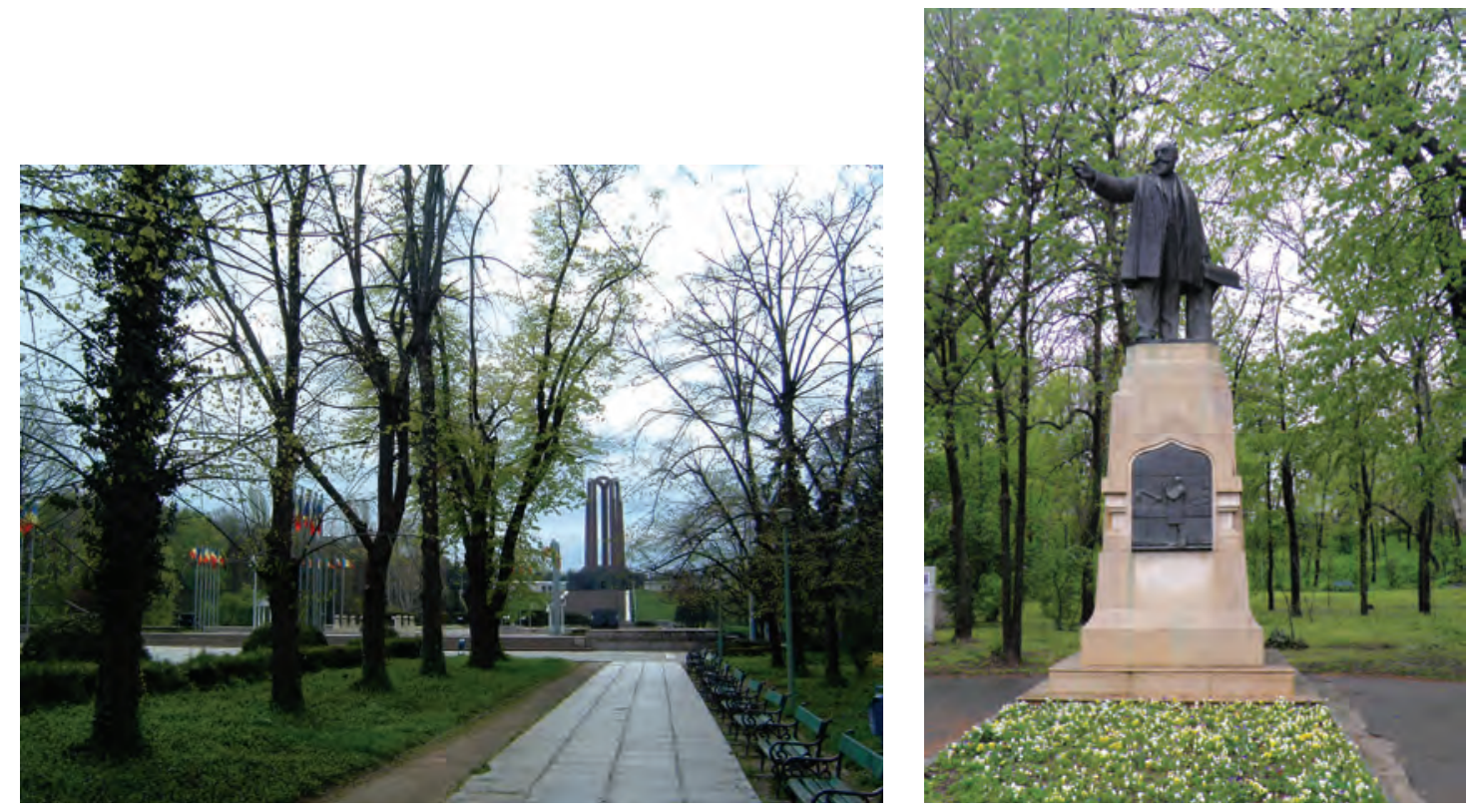

Fig. 4 - statuia Dr. C. I. Istrati (2014)

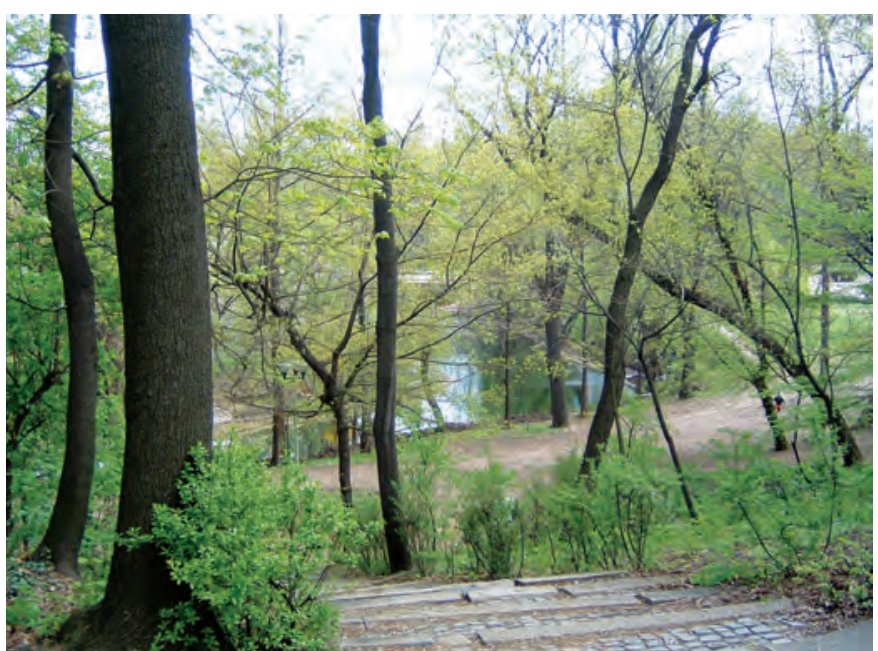

Fig. 2, sus - amenajarea liniară a platformei inferioare (2004)

Fig. 3 - amenajare peisageră cu caracter romantic (2004)

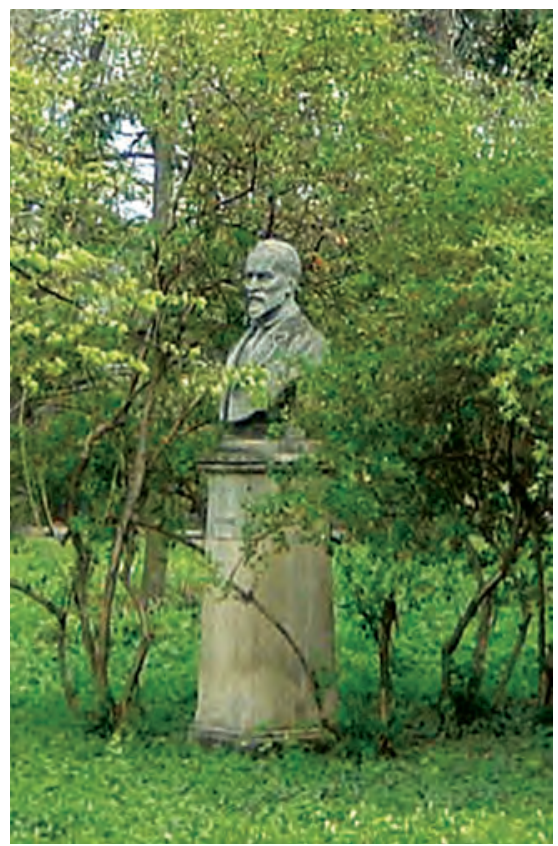

Fig 5 - bustul lui

G. Coșbuc (2004) 
parterul de iarbă și plantație floricolă - alcătuiește un peisaj deosebit de bine stăpînit, cu calități estetice remarcabile. Trebuie subliniat rolul important al plantației în configurarea compoziției peisagistice, fapt care conferă acesteia o valoare culturală cu totul deosebită.

\section{Valoarea componentelor plastice}

Calităților cu totul deosebite ale ansamblului li se adaugă valorile unor componente artistice punctuale, cum sunt: - „statuia Dr. Constantin I. Istrati” (Fig. 4), comisarul general al expoziției jubiliare din 1906, precum și busturile lui Nicolae Bălcescu, George Coșbuc (Fig. 5) și Alexandru Sahia;

- cele două statui ale giganților, lucrări ale sculptorilor Dimitrie Paciurea (Fig. 6) și Filip Marin (Fig. 7), care împreună cu „Nimfa adormită” a lui Carol Storck, strămutată în prezent în parcul Herăstrău - alcătuiau grupul statuar „Grota Giganților”, amplasată inițial în fața unei peșteri artificiale în mijlocul căreia era un bazin cu apă;

- cele două fântâni decorative realizate în a doua jumătate a secolului al XIX-lea, una edificată la comanda primarului capitalei George Grigore Cantacuzino Nababul, cunoscută ca „Fântâna George Gr. Cantacuzino” (Fig. 8), iar cealaltă construită ceva mai târziu pe locul fostului chioșc din Grădina Filaret (Fig. 9);

- „Mormântul Eroului Necunoscut” (Fig. 10), monument al sculptorulului Emil Willy Becker, creat în 1923 din inițiativa Societății Mormintelor Eroilor, condusă de Regina Maria.

Foto, sus: Fig. 6 - statuia Gigantului de Dimitrie Paciurea (2004) Fig 7 - statuia Gigantului de Franz Storck (2004)
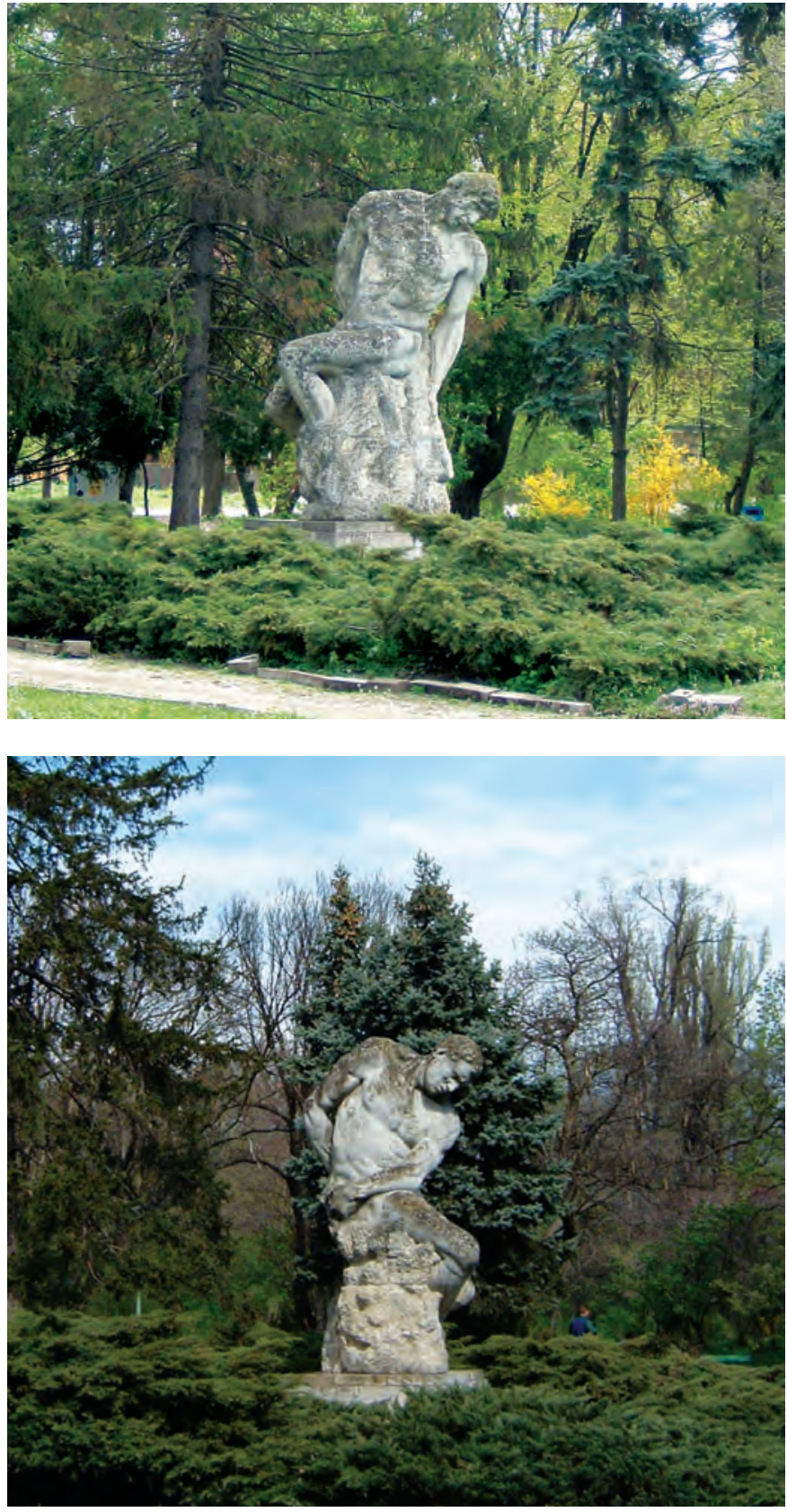
Foto: Fig. 8, sus - Fântâna George Gr. Cantacuzino (2004) Fig. 9, jos, stânga - Fântâna construită pe locul fostului chioșc din Grădina Filaret (2004)

Fig. 10 - Mormântul Eroului Necunoscut (2014)

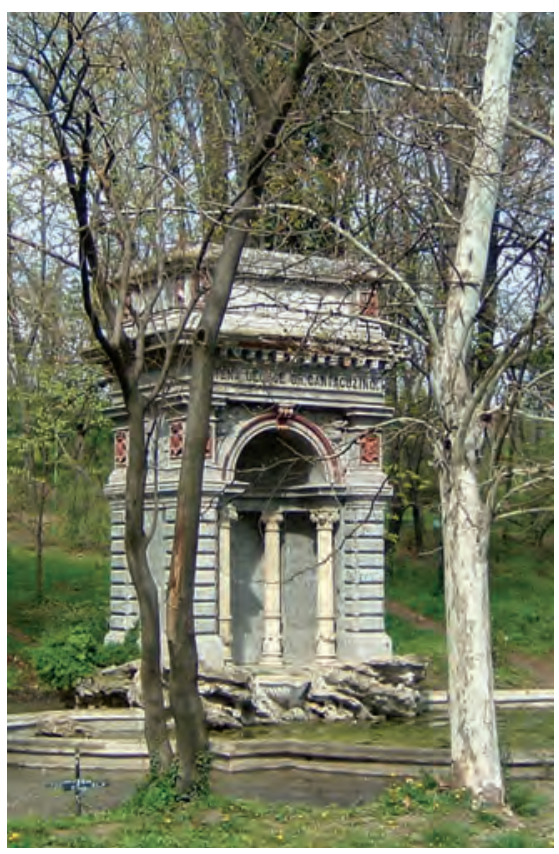

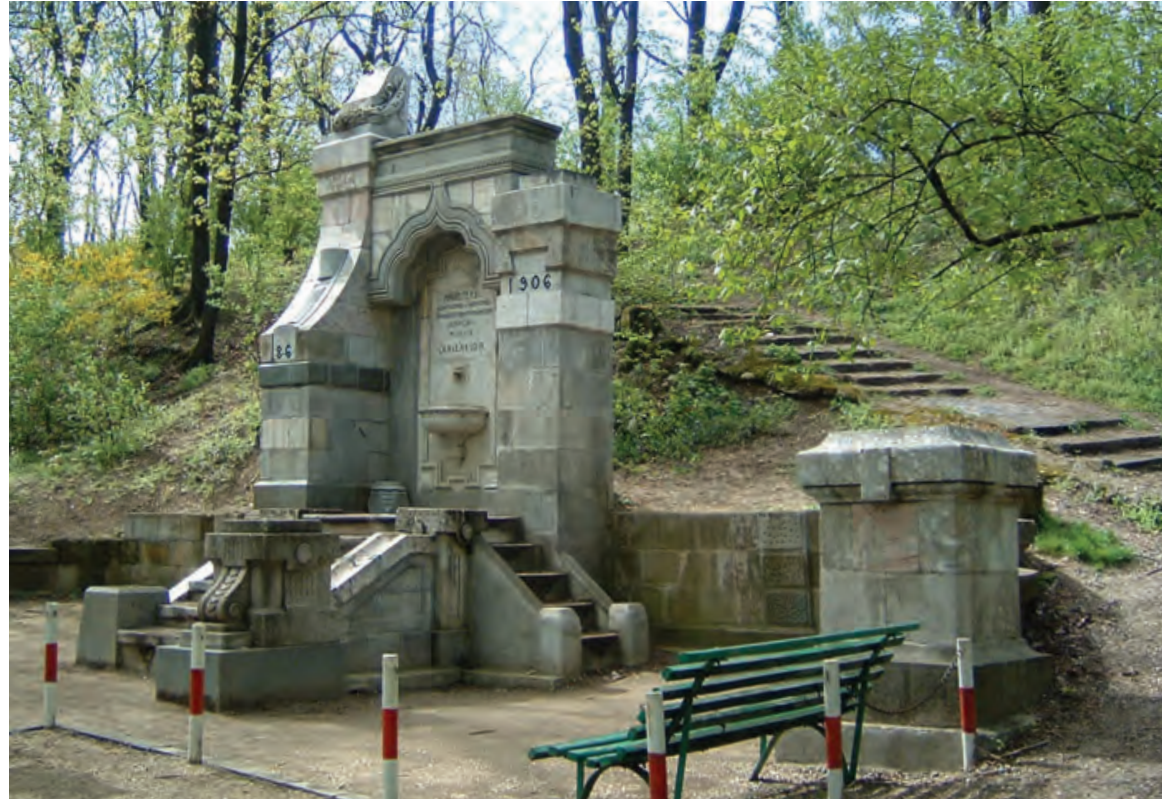

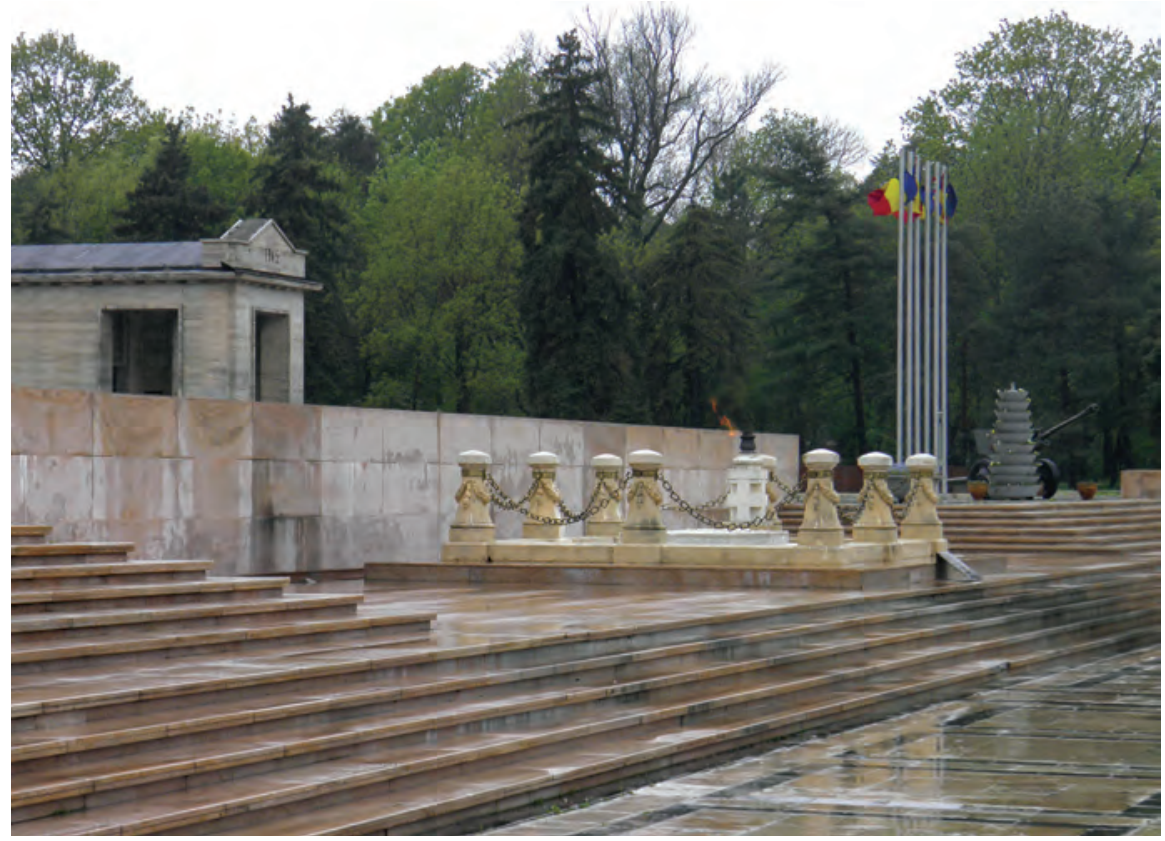


Mai trebuie amintite și componentele arhitecturale și artistice ale unor construcții semnificative, valoroase atât prin concepția de ansamblu și detaliile remarcabile, cât și prin calitatea materialelor puse în operă, cum sunt:

- „Arenele Romane” (Fig. I I și I2), teatru în aer liber cu o capacitate de 5.000 de locuri, construit de arhitectul Leonida Negrescu și inginerul Elie Radu;

- „Monumentul Eroilor” (Fig. I3, I4, I5 și 16), realizat după proiectul arhitectului Nicolae Cucu și un colectiv al Institutului Proiect-București, condus de arhitectul Horia Maicu.

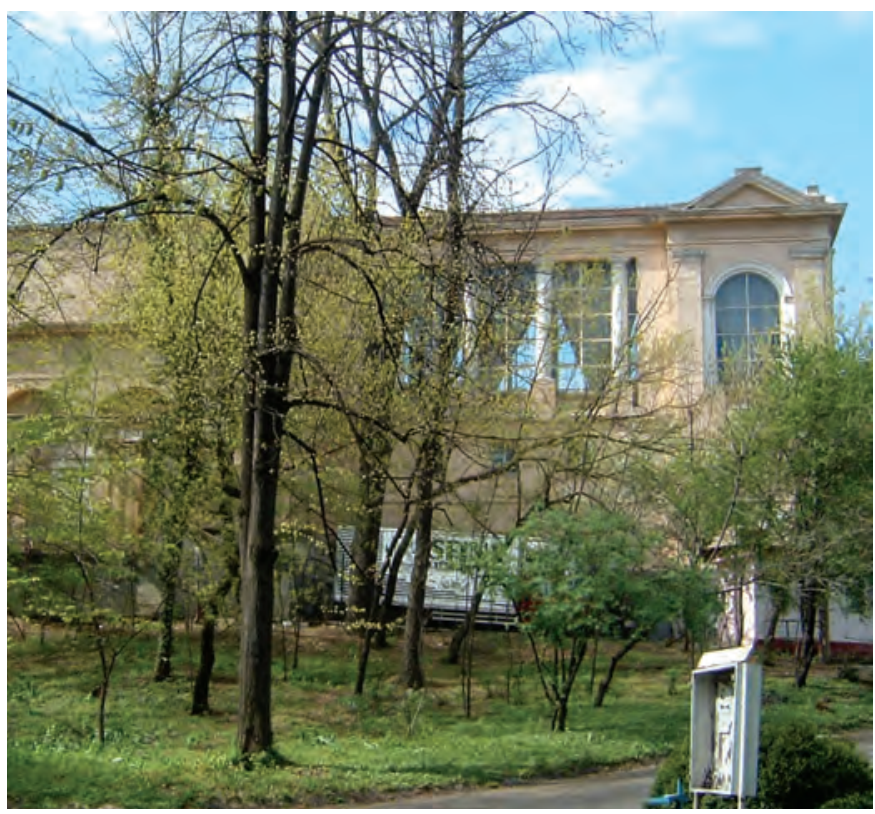

Foto

Pagina 12:

Fig. I I (sus) - Arenele romane, vedere laterală (2004)

Fig. 12 - Arenele romane, vedere intrarea principală (2004)

Pagina 13, stânga sus:

Fig. 13 - Monumentul Eroilor, partea stângă a exedrei (2014)

Fig. 14 - Monumentul Eroilor, corpul principal, vedere dinspre axul central (2004)

Fig. I5 - Monumentul Eroilor, corpul principal, vedere interioară a zonei de acces (20l4)

Fig. 16 - Monumentul Eroilor, corpul principal vedere interioară generală (2014)

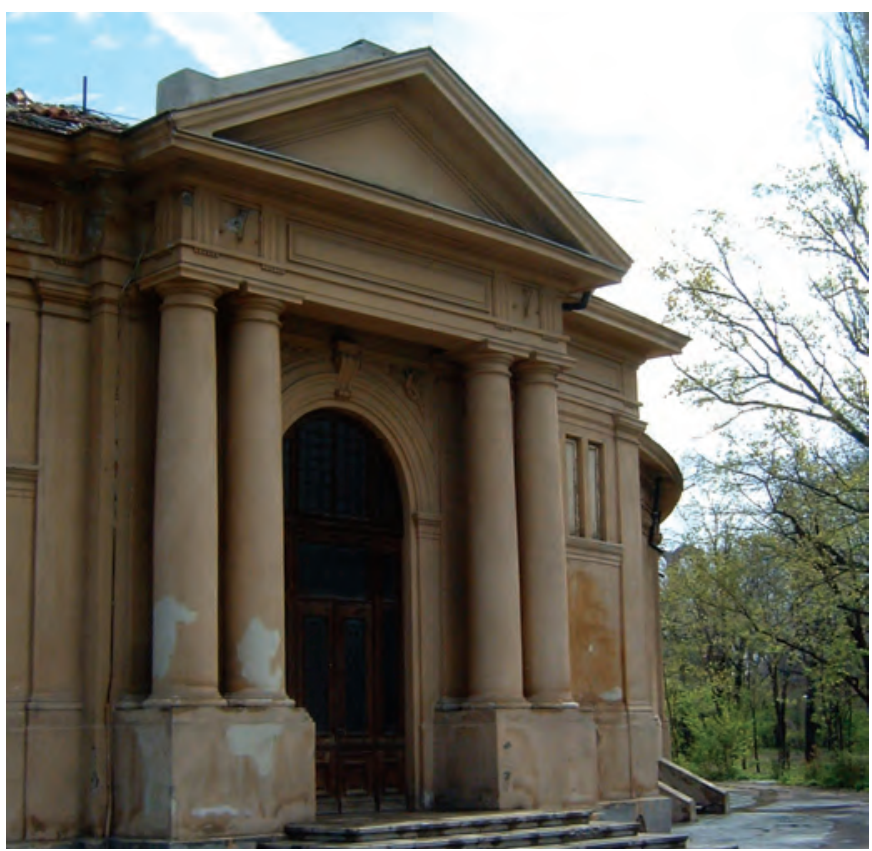



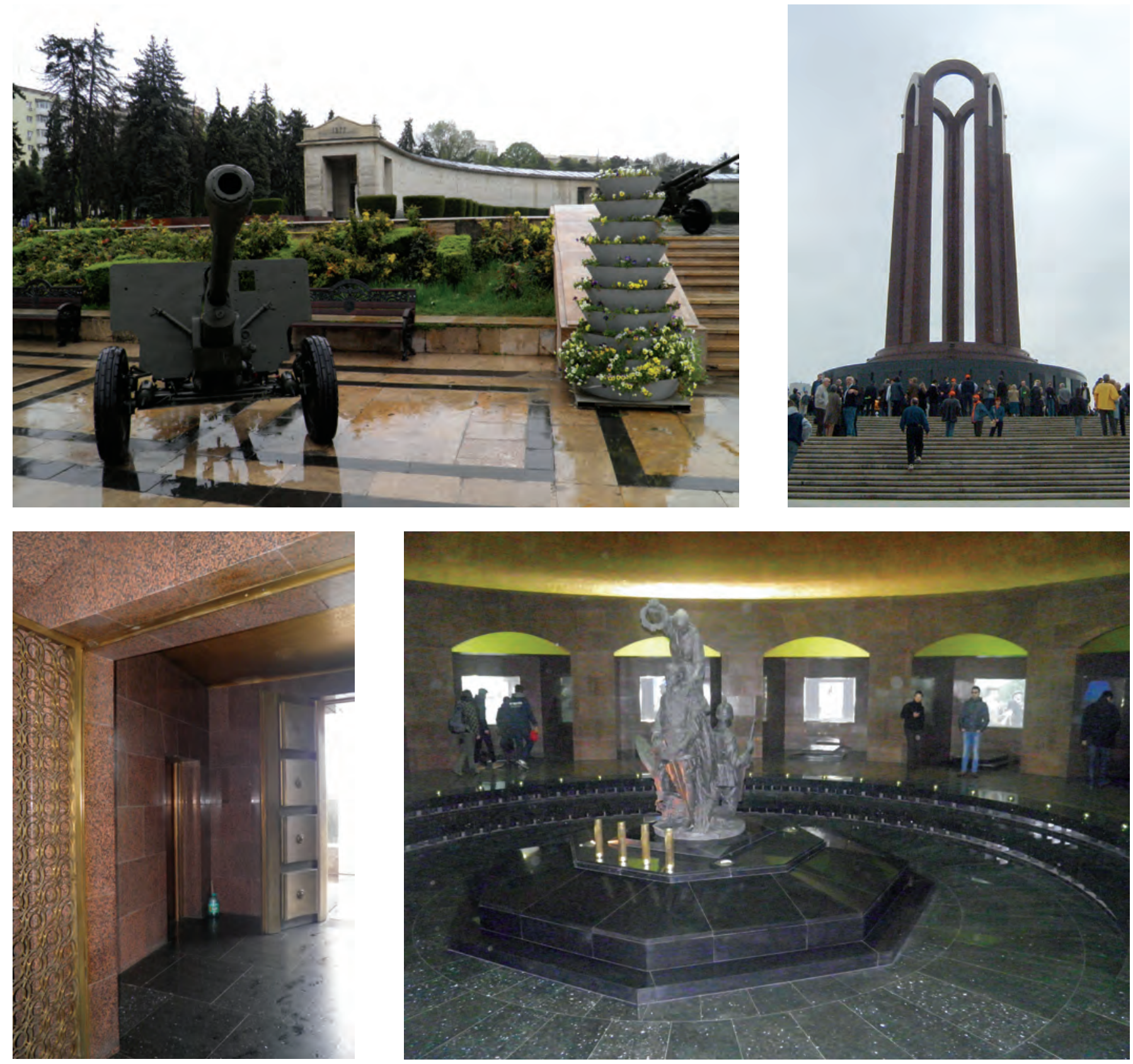
În aceeași categorie a valorilor arhitecturale trebuie amintite alte două construcții legate de evoluția istorică a parcului și intrate în memoria culturală a locuitorilor Capitalei, dar care prin modul de exercitare adrepturilor de proprietate sunt rupte formal de contextul de ansamblu al parcului:

- „Castelul Țepeș Vodă”, (Fig. 17) inițial un castel de apă proiectat de Ștefan Burcuș și Victor Ștefănescu, având ca antreprenori pe arhitecții Scarlat Petculescu și Leopold Schindl, este realizat ca $\circ$ clădire romantică ce imaginează o posibilă replică a cetății Poenari din Argeș, presupusă reședință a lui Vlad Țepeș;

- Biserica „Schimbarea la Față”, „Cuțitul de Argint” sau Bărbătescu Nou (Fig. I8), o replică a bisericii Sf. Nicolae din lași, este realizată după proiectul lui Nicolae Ghica Budești (deși Catalogul Casei Artelor din 1906 consemnează faptul că planurile au fost realizate și

Foto

Fig. 17 (sus) - Castelul Țepeș Vodă,vedere dinspre parc (2004-076)

Fig. 18 - Biserica Cuțitul de Argint, vedere laterală (2004-047)
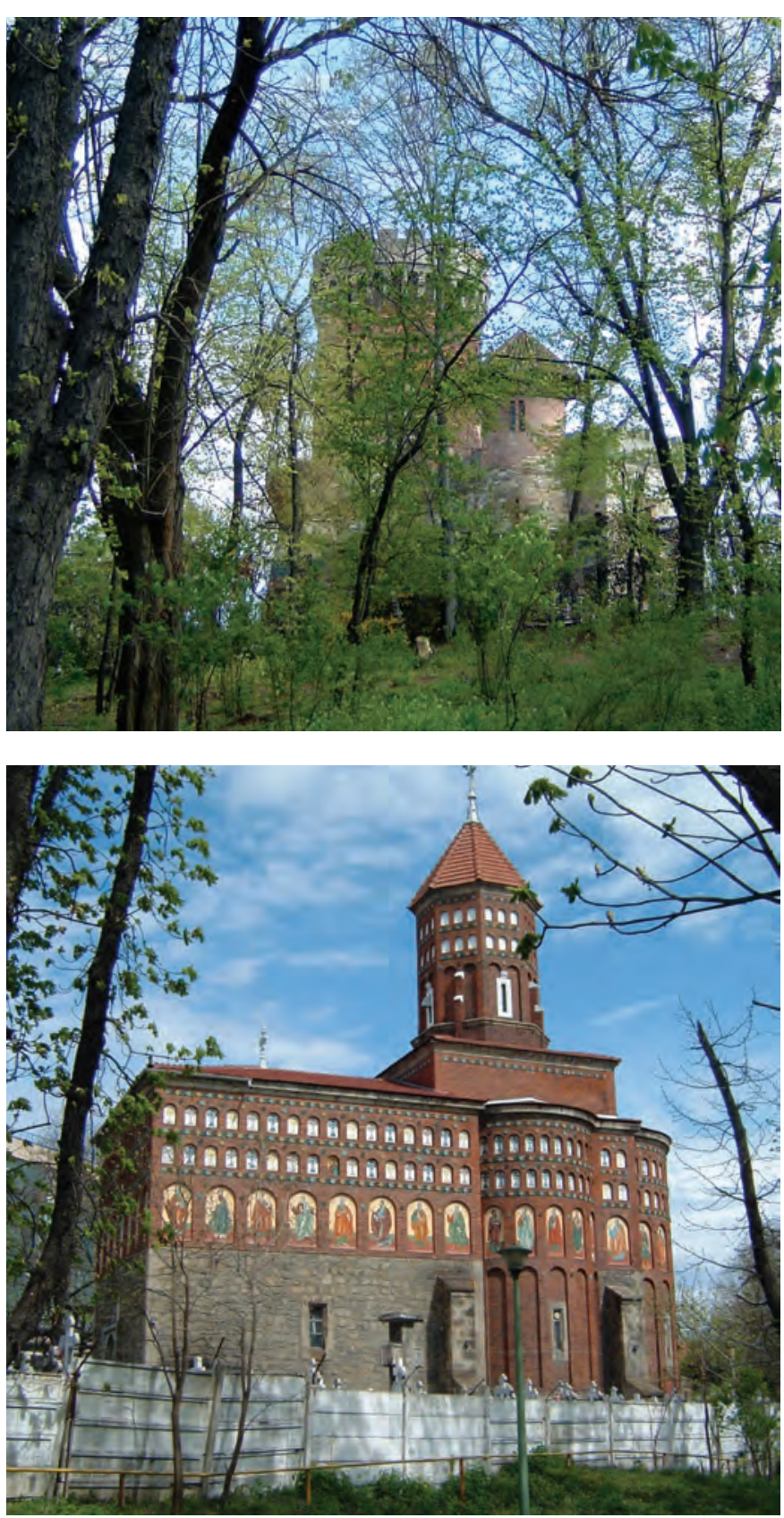

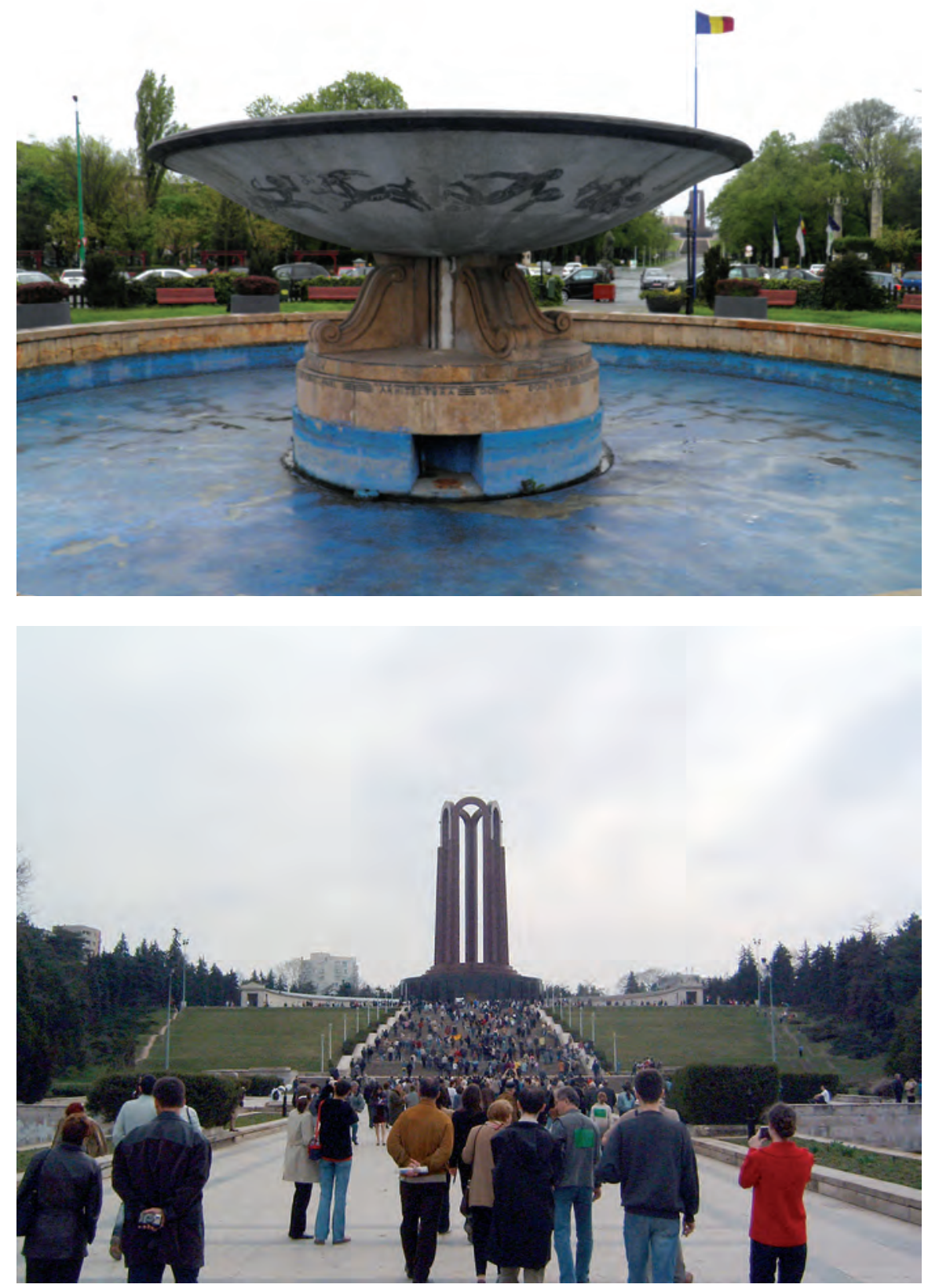

Fig. 19 - Fântâna Zodiacului, vedere spre axul central al Parcului Carol I (20 |4)

Fig. 20 - Monumentul Eroilor, vedere cu podul și accesul pe esplanada superioară (2004) 
lucrările au fost coordonate de arh. George Sterian) în prezent este separată printr-un gard masiv din beton de trupul parcului din care făcea parte inițial.

\section{Notorietatea autorilor}

Pe lângă numele celebre ale arhitecților, inginerilor și sculptorilor deja amintiți pentru aportul considerabil înglobat în lucrările existente în Parcul Carol I, la realizarea parcului au contribuit generații succesive de arhitecți renumiți.

Astfel, printre cei care au participat la realizarea parcului pot fi menționați:

- în etapa din 1906: arhitectul și peisagistul francez Édouard Redont, autorul proiectului parcului; arhitectul Ștefan Burcuș, autorul Planului General pentru Expoziția Generală Română; arhitectul lon D. Berindei, inspectorul lucrărilor pentru expoziția jubiliară, personalitate a generației fondatorilor școlii românești de arhitectură;

- în etapa din 1935: arhitectul Octav Doicescu, care proiectează ca element de articulare a spatiului public urban cu cel al parcului Fântâna Zodiacului (Fig. 19), operă a sculptorului Mac Constantinescu, realizată de August Schmiedigen și Dorin Pavel;

- în etapa din 1963: arhitectul Nicolae Cucu și un colectiv al Institutului Proiect-București condus de arhitectul Horia Maicu, care realizează proiectul axului central, al esplanadei din zona accesului principal și edificiul Monumentul Eroilor (Fig. 20, 2 I, 22 și 23).

\section{Dimensiunea funcțional-simbolică}

Funcțiunea de agrement și de înfrumusețare a orașului, căreia i se adaugă cea de igienizare - prin asanarea locului mlăștinos și prin prezența benefică a vegetației pentru nou apăruta industrie în zonă - sunt alte caracteristici care au continuitate și care, și astăzi caracterizează parcul pe deplin.
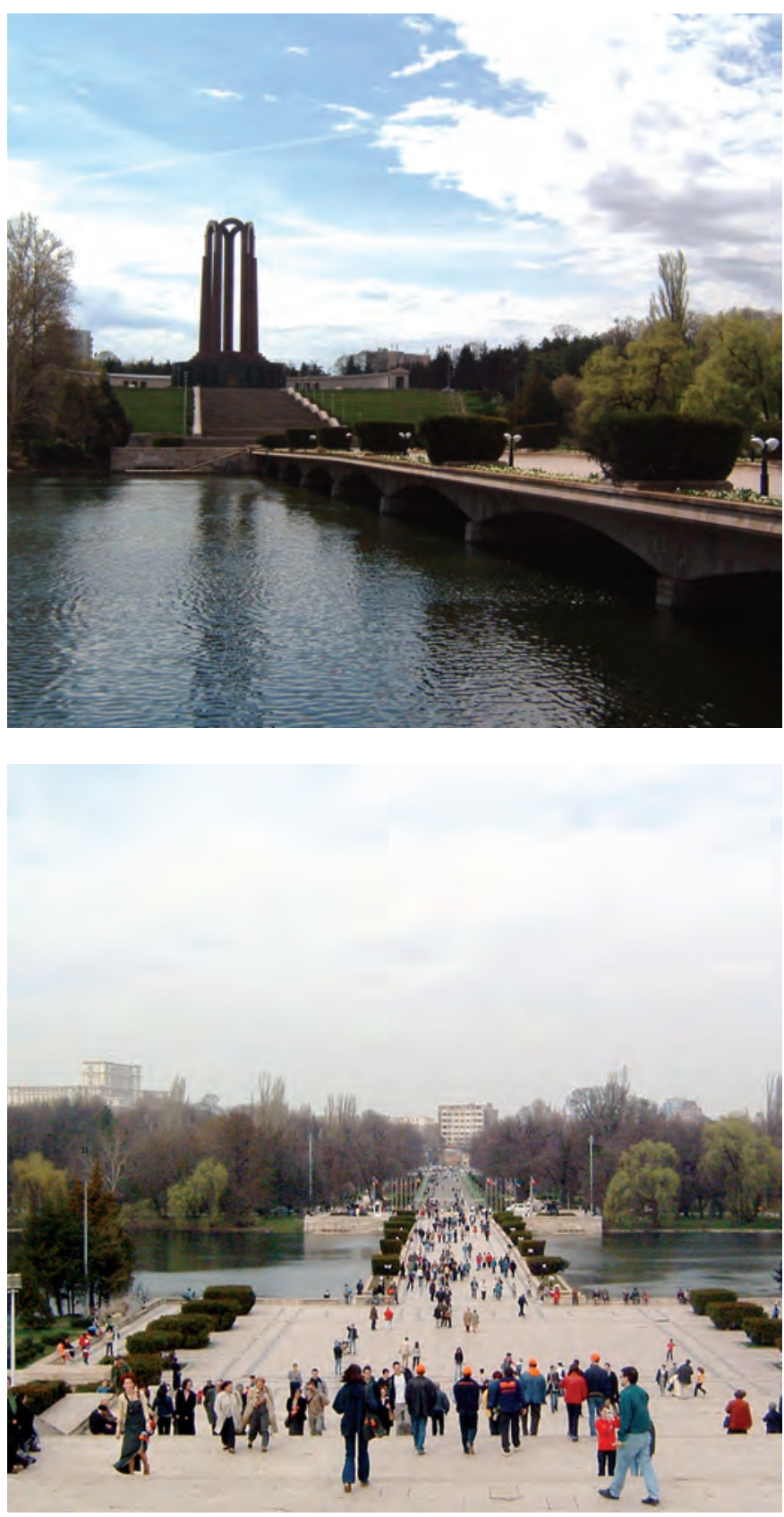

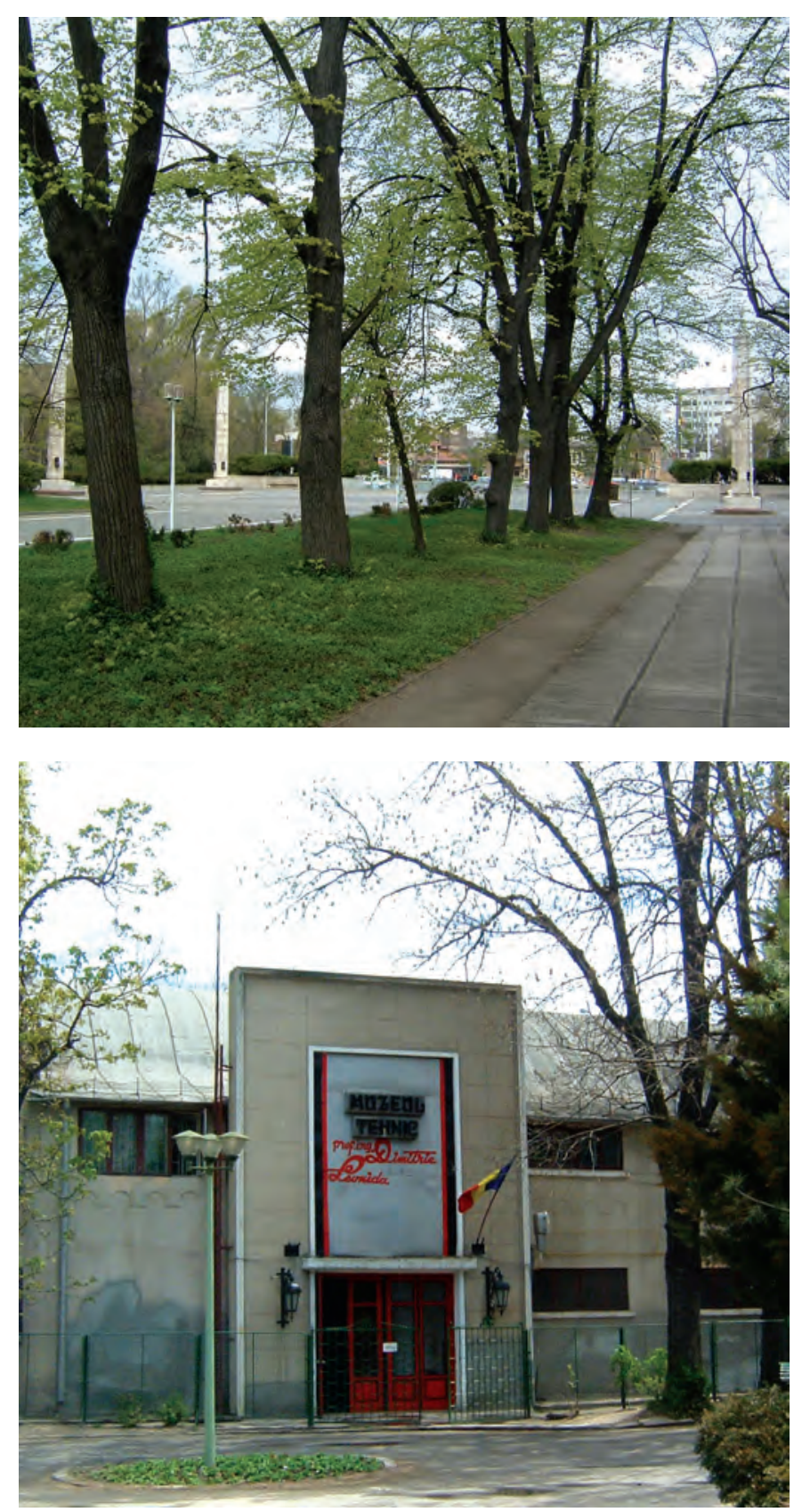

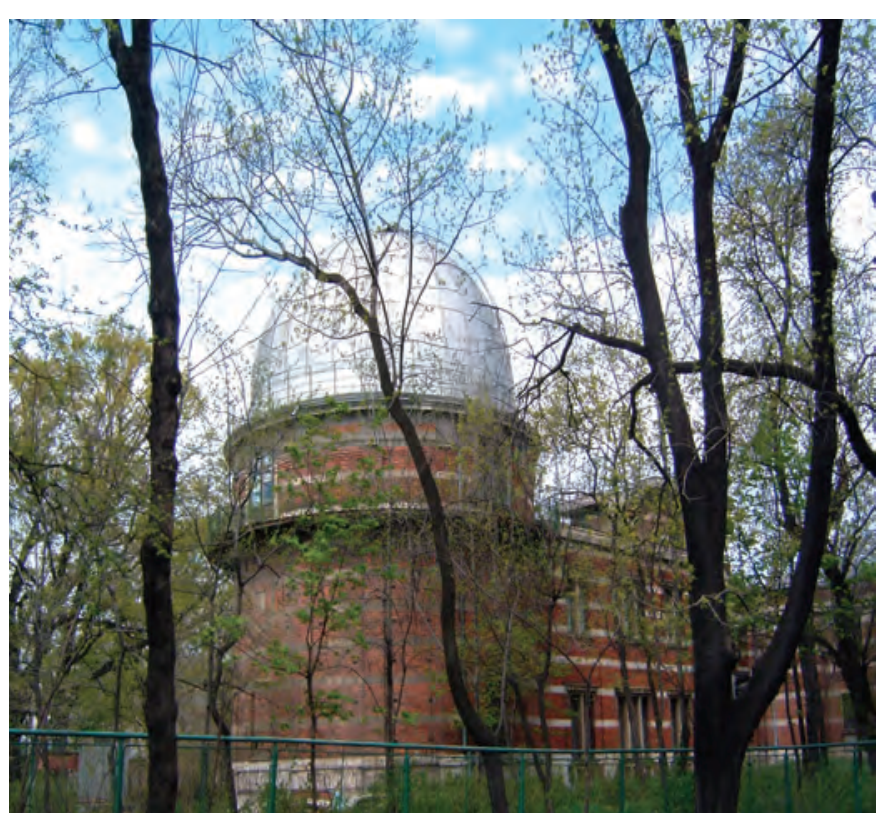

Foto

Pagina 16:

Fig. 21 , sus - Monumentul Eroilor, vedere axială a zonei de acces pe esplanada superioară (2004)

Fig. 22 - Vedere dinspre Monumentul Eroilor cu axul compozițional central al parcului (2004)

Pagina 17:

stânga sus: Fig. 23 - Vedere cu axul compozițional central înspre intrarea principală în Parcul Carol I (2004)

Jos: Fig. 24 - Muzeul Tehnicii Prof. ing. Dimitrie Leonida, accesul dinspre parc (2004)

Fig. 25 - Institutul Astronomic Bosianu,vedere din Parcul Carol I (2004) 
Din punct de vedere functional, parcul a fost încă de la început conceput atât ca un loc de agrement și de loisir cultural, cât și ca un spațiu public fie pentru manifestări cu caracter aniversar-comemorative legate de memoria eroilor naționali, fie ca loc de reprezentare pentru o anumită etapă de dezvoltare economică și comercială, prin expozițiile pe care le-a adăpostit.

Caracterul actual complex al parcului răspunde atât prin componente, cât și ca ansamblu, celor două dimensiuni funcționale predominante și cu tradiție.

Astfel, pe parcursul întregii sale existențe Parcul Carol I a deținut funcțiuni multiple dezvoltate în timp ca pondere și semnificație, caracterul comemorativconferindu-i o particularitate aparte. Acestei componente i se adaugă în mod fericit funcțiunile celorlalte construcții păstrate în prezent atât în interiorul actualului perimetru al parcului (Arenele Romane și Monumentul Eroilor), cât și pe parcelele adiacente care, fie au fost desprinse din corpul acestuia (Muzeul Tehnicii - prof. ing. Dimitrie Leonida (Fig. 24), Castelul Țepeș Vodă și Biserica Schimbarea la Față - Cuțitul de Argint sau Bărbătescu Nou), fie au fost permanent într-o relație de vecinătate, cum este Institutul Astronomic [Constantin] Bosianu (Fig. 25).

Toate acestea conferă ansamblului urbanistic, arhitectural și peisagistic Parcul Carol I un amplu caracter culturalformativ, deținut încă din prima etapă a realizării sale, care însă ar putea fi pus în valoare mult mai eficient printr-o abordare unitară a tuturor entităților implicate în procesul de administrare a acestui complex cultural și istoric.

\section{Criteriul referitor la frecvență (unicitate și raritate)}

La acest criteriu s-au avut în vedere anumite aspecte, care rezultă din datele istorice și din celelalte criterii prezentate anterior. Se poate afirma faptul că, în configurația sa actuală, Parcul Carol I deține statutul de ansamblu monument istoric cu valoare de unicat la nivel național prin cea mai mare parte a caracteristicilor sale. Parcul Carol I este semnificativ pentru începutul secolului al XX-lea, desi în timp a suferit mai multe schimbări inclusiv prin înlocuirea unor pavilioane ale diferitelor expoziții cu zone de vegetație. O importantă caracteristică a sa este îmbinarea savantă a celor două stiluri frecvent aplicate în epocă: cel geometric și axial (cu caracter monumental) și cel de esentă romantică, a cărui principală caracteristică este neregularitatea conformației oglinzii de apă, a dispunerii vegetației și a aleilor.

Caracterul romantic al parcului este special conceput pentru a asigura o legătură coerentă atât cu particularitățile de relief, cât și cu structura ordonată a celeilalte componente cu caracter geometric. (Fig. 26 și 27)

Combinația dintre caracteristicile amenajării peisagistice mai sus mentionate și caracterul complex al functiunilor pe care le au construcțiile din actuala incintă a parcului și de pe parcelele adiacente îi conferă acestuia un caracter cu totul inedit, unic în felul său.

\section{Criteriul referitor la caracterul memorial-simbolic}

Acest criteriu are drept scop stabilirea valorii imobilului din punctul de vedere al dimensiunii memorial- simbolice pe care o reprezintă Parcul Carol I, nu doar prin componentele sale sau prin caracteristicile de ansamblu urbanistic, arhitectural și peisagistic, ci și prin componenta memorială generată de evenimentele istorice care s-au desfășurat în acest loc.

Astfel, chiar amplasamentul ales pentru realizarea sa este încărcat de valoare istorică, ținând cont atât de faptul că pe Câmpia Filaretului Nicolae Bălcescu, Ion Ghica, Alexandru G. Golescu și Christian Tell au întemeiat în I843 societatea Frăția (nucleul care a premers Revoluția de la 1848), cât și de faptul că cele două Adunări din I I și 15 iunie 1848 s-au desfășurat tot în acest perimetru. Cu acel prilej, guvernul provizoriu de la 1848 a denumit acest 

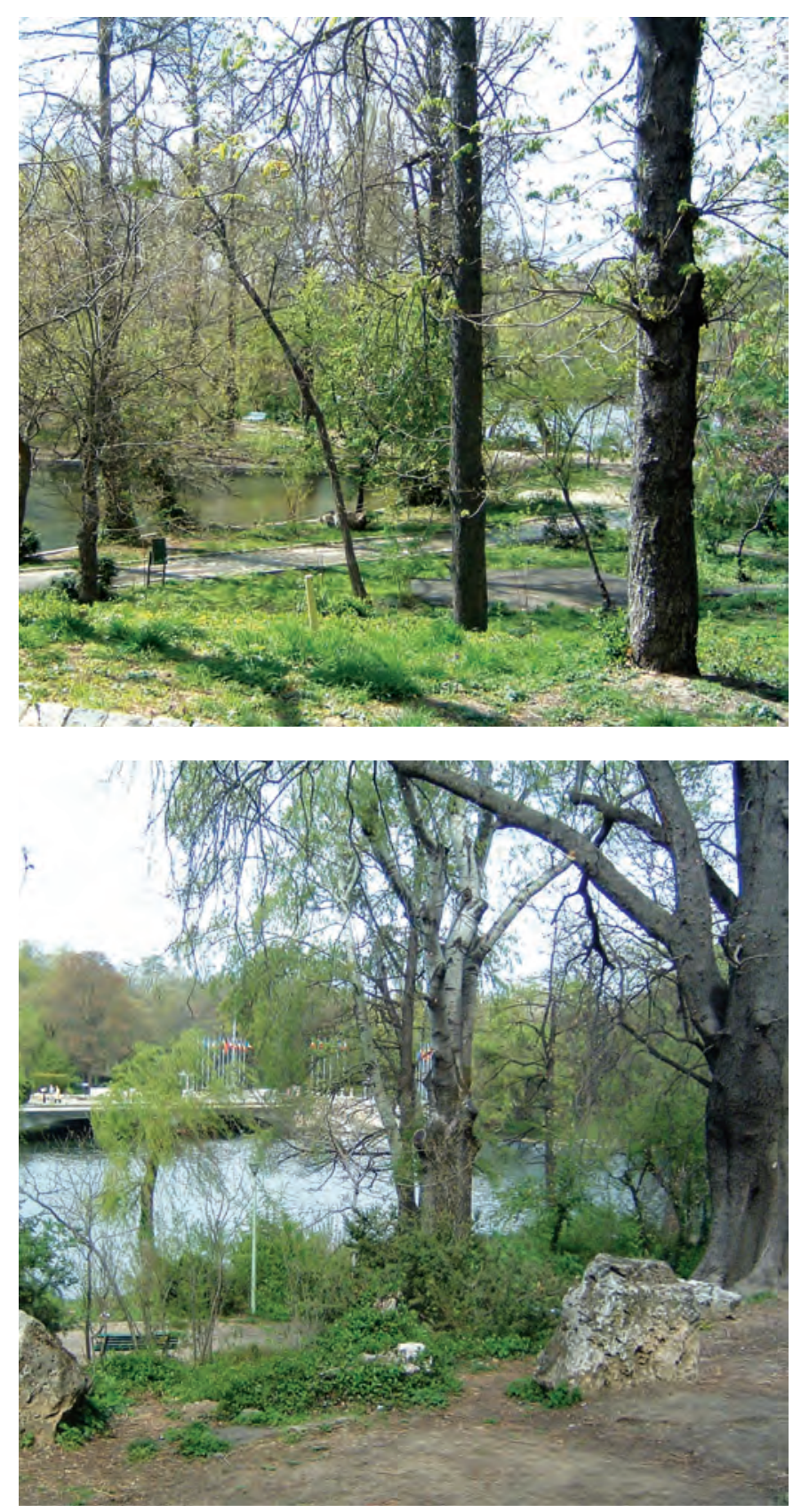

loc Câmpia Libertății, memorie toponimică pe care nici perioada comunistă nu a șters-o și care persistă și în denumirea străzii I I lunie și a Pieței Libertății.

Realizarea parcului în anul 1906 marchează aniversarea a 40 de ani de domnie ai Regelui Carol I, a 25 de ani de la proclamarea Regatului și a 1800 de ani de la venirea primilor colonisti romani, prilej cu care se ia decizia de a organiza Expoziția Generală Română. Această manifestare cu caracter internațional reprezintă un moment în care România arată Europei că a ajuns la un stadiu de dezvoltare economică și de prestigiu politic, care îi permit săorganizeze expoziții universale, la fel ca alte state din Europa, în general, și din Europa centrală, în special. Un alt aspect istoric remarcabil se referă prefigurarea caracterului comemorativ al platformei superioare a parcului (pe care se afla Palatul Artelor, devenit ulterior Muzeul Militar Național) și care, prin Decretul Regal nr. 4836/I5 nov. 1919, emis de Regele Ferdinand, este cedată „de veci Ministerului de Război”, cu clădirile și terenul în scopul construirii unui muzeu militar și a unui Pantheon al Eroilor Neamului.

Tot în aceeași categorie se încadrează dezvelirea la 17 mai 1923 a monumentului Mormântul Eroului Necunoscut, amplasat în fața Muzeului Militar Național și realizat din inițiativa Societății Mormintelor Eroilor, condusă de Regina Maria. Această manifestare la care participă familia regală, guvernul și membrii corpului diplomatic reprezintă un alt moment cu caracter memorial-simbolic, chiar dacă a fost umbrit de schimbarea repetată a amplasamentului inițial, începând cu noaptea de 22/23 decembrie 1958, când este strămutat la Mausoleul de la Mărășești.

Mai puțin prezente în memoria colectivă sunt cele două manifestări găzduite de Parcul Carol I: Expoziția Industrială din septembrie 1921 și prima ediție a expoziției urbanistice anuale Luna Bucureștiului,

Fig. 26 - 27, relații de amenajare peisagere (2004) 
organizată la sugestia primarului Alexandru G. Donescu între 9 mai și 9 iunie 1935.

Dacă momentele anterioare perioadei comuniste și-au pierdut caracterul predominant politic, căpătând o aură istorică dominantă, memoria perioadei comuniste este încă prezentă în mod apăsător, sub spectrul său politic nefast, ceea ce conduce la numeroase discutii si dispute referitoare la calitătile și valoarea actuală a ansamblului urbanistic, arhitectural si peisagistic a Parcului Carol I.

Astfel, „Monumentul Eroilor”, construit în anul 1963 ca un element dominant ce definește vocația memorialsimbolică de interes național a Parcului Carol I, reprezintă încă și astăzi, din păcate, un sistem politic care a confiscat dorința legitimă a Regelui Ferdinand de a ridica un Pantheon al Eroilor Neamului. Una dintre modalitățile folosite în acest sens este adăugarea sintagmei „,pentru Socialism" la una dintre variantele denumirilor inițiale, fără conotație politică: Monumentul Luptei pentru Libertatea Poporului și a Patriei. Această conduită, susținută de o cunoaștere trunchiată a istoriei a condus la umbrirea calităților urbanistice, arhitecturale și artistice ale întregului ansamblu, culminând în zilele noastre cu impulsul de sorginte barbară de a distruge mărturiile și valorile materiale ale unei epoci istorice pentru a certifica dezicerea de un sistem care a funcționat exact în baza acestui principiu și mod de acțiune. Doar manifestările civice și concluziile pertinente ale studiului realizat de U.A.U.I.M. cu acel prilej au stopat distrugerea unor componente memorial-simbolice materializate de un sistem politic care le deturnase de la sensul inițial.

În acest sens, trebuie afirmat cu responsabilitate faptul că distrugerea simbolurilor sau eludarea mărturiilor istorice nu face mai bună sau mai rea evoluția istorică a unui popor, iar prezența acestora reflectă, pe lângă gradul de maturitate al unei națiuni, și garanția cunoașterii momentelor neplăcute, ca $\circ$ pe $\circ$ condiție necesară pentru evitarea greșelilor din trecut. Golirea de simbolurile unui sistem de care dorim să ne debarasăm se poate realiza, nu numai în acest caz, atât prin redarea sensului inițial - denaturat vreme de aproape jumătate de secol - printr-o cunoaștere cât mai corectă a istoriei care ne-a marcat existența, cât și prin conservarea și evidențierea acelor caracteristici semnificative pentru valorile culturale naționale, indiferent de momentul istoric în care acestea au fost realizate.

Acestor dimensiuni programatice li se adaugă și alte aspecte legate de memoria istorico-geografică a locului, de dezvoltarea urbanistică și demodernizarea Capitalei, de strategia transformării acesteia dintr-un târg cu caracter oriental într-o metropolă europeană, de cultura noastră modernă, precum și de reprezentanții săi, toate conferind Parcului Carol I o valoare memorial-simbolică excepțională.

Prin calitățile evidențiate - referitor la valoarea arhitecturală, urbanistică, artistică, peisagistică, memorială, compozițională și de raritate - Parcul Carol I constituie un mozaic cultural de valoare excepțională, reprezentativ la nivel național pentru epoca modernă, atât ca ansamblu, cât și prin componentele sale, care trebuie conservat, întreținut și pus în valoare prin alocarea unui mod de funcționare și de utilizare corespunzător.

În concluzie, deși a suferit numeroase intervenții în timp, valoarea de ansamblu urbanistic, arhitectural și peisagistic a Parcului Carol I este semnificativă atât prin încărcătura istorică deosebită, cât și prin valoarea plantațiilor și amenajărilor peisagistice, care odată ajunse la maturitate împlinesc viziunea proiectanților și conferă ansamblului personalitate și coeziune stilistică și compozițională. Traseele, axele majore și nu în ultimul rând elementele arhitecturale și de for public care alcătuiesc ansamblul parcului constituie de asemenea valori semnificative din punct de vedere artistic și compozițional. 
Reglementările cu caracter general rezultate în urma constatărilor evidențiate anterior referitor la valorile culturale pe care le deține Parcul Carol I sunt prezentate detaliat în studiul elaborat pentru P.U.Z. Parcul Carol I, dar care nu fac în totalitate obiectul acestei lucrări.

Trebuie subliniat că dintre reglementările formulate în urmă cu 12 ani, doar o parte au fost puse în practică. Acestea aveau în vedere, pe de o parte, mutarea monumentului Mormântul Eroului Necunoscut pe amplasamentul inițial, gest necesar pentru redarea imaginii originare și respectarea adevărului istoric, iar pe de altă parte, reparația morală referitoare la memoria confiscată vreme de jumătate de secol, prin alocarea unei functiuni cu caracter memorial pentru Monumentul Eroilor, astfel încât prin amplasamentul și caracterul funcțional, acest edificiu să împlinească un vis național de cinstire a eroilor și valorilor neamului. Cu toate acestea, rămân în continuare numeroase reglementări încă neluate în considerare, ceea ce diminuează o percepere pe deplin favorabilă a valorilor culturale.

În esență, ansamblul urbanistic, arhitectural și peisagistic Parcul Carol I beneficiază de un regim multiplu de protecție, care poate să asigure conservarea și punerea în valoare atât a valorilor culturale instituite, cât și a celor identificate prin diverse studii de specialitate.

Apare, însă, o problemă esențială care privește modul de administrare, de întreținere și de gestionare a acestor valori culturale.

Relațiile organice de interdependență, stabilite în timp între componentele sale, fac nocivă orice modificare a calităților de ansamblu ale Parcului Carol I, prin exacerbări ale dreptului de proprietate manifestate ca forme de extrudare sau de enclavizare ale unor părți care istoricește proprietate manifestate ca forme de extrudare sau de enclavizare ale unor părți care istoricește îi aparțin. De aceea, una dintre principalele recomandări se referă la studierea posibilităților de înființare și de organizare a unei agentii de monitorizare și de gestionare a interventiilor de întretinere, de conservare si de punere în valoare ale ansamblului urbanistic, arhitectural și peisagistic Parcul Carol I, precum și a modalităților de desfășurare a activităților diferitelor instituții care ființează pe teritoriul acestuia.

\section{Referinte}

Drăgan, V. E. (2006). „Studiu istoric pentru Parcul Carol I, imobil situat în Piața Libertății, sectorul 4, delimitat de: Piața Libertății, Str. G-ral Candiano Popescu, Calea Șerban Vodă, Str. Cuțitul de Argint și str. dr. Constantin Istrati. Analiza valorilor culturale ale imobilului și ale zonei învecinate; reguli generale de interventie pentru conservarea valorilor culturale și integrarea în zonă”, București: studiu nepublicat.

Ministerul Culturii, (2016). Lista Monumentelor Istorice (pp.498-

730). Bucuresti: Monitorul Oficial al României, Partea I, Nr. 540 din 17.07.2008.

Ministerul Culturii și Cultelor, (2008). Ordin 2260/2008 privind aprobarea Normelor metodologice de clasare și inventariere a monumentelor istorice, București: Monitorul Oficial al României, Partea I, Nr. 540 din 17.07.2008.

Regele Ferdinand, (1919). Decret Regal nr. 4836/I5 nov. 1919. U.A.U.I.M., (2005). „Punctul de vedere al U.A.U.I.M. în legătură cu proiectul de amplasare a Catedralei Patriarhale în Parcul Carol I din București”. București: studiu nepublicat.

Sursele imaginilor

Fig. I - extras din: Drăgan, V.-E. (2006);

Fig. 2 - Fig. 27: fotografii realizate de autor.
Valeriu-Eugen DRĂGAN

este conf. dr. arh. al UAUIM București 